Należy mieć zatem nadzieję, że kolejne wydawnictwa tej serii, zapowiedziane przez redaktorkę we „Wstępie” nie tylko będą miały równie intrygujące podtytuły, ale być może unikną ,grzechów” zwykle przydarzającym się tym, którzy są pionierami i przecierają szlaki innym.

Edyta Głowacka-Sobiech

\title{
„Salve lux post tenebras” Historia instytucji oświatowych w budynku dawnego gimnazjum św. Elı̈biety przy ulicy Dawida we Wrockawiu, pod red. Jolanty Szablickiej-Żak i Agnieszki Gryglewskiej
}

DOI: 10.14746/BHW.2016.34.12

Wydany nakładem Uniwersytetu Wrocławskiego tom studiów stanowi monograficzne opracowanie zarówno historii budynku dawnego gimnazjum św. Elżbiety, jak i dziejów instytucji oświatowych mieszczących się w jego progach. Książka prezentuje się imponująco pod względem edytorskim, opatrzona jest obszernym materiałem ikonograficznym, bardzo starannie dobranym i wkomponowanym w tekst. Ilustracje, co niestety wciąż stanowi rzadkość we współczesnych publikacjach, są w monografii integralną częścią wykładu, a ich przemyślane rozplanowanie ułatwia odbiór i lekturę tekstu. Tytuł sugerujący monograficzne ujęcie dziejów budynku gimnazjum św. Elżbiety, może nieco wprowadzać w błąd, obiecując znacznie mniej niż zawartość książki będącej wyczerpującym omówieniem dziejów budynków położonych na Polach Stawowych (w rejonie obecnych ulic Jana Władysława Dawida, Joannitów i Glinianej) oraz instytucji oświatowych i opiekuńczych z nimi związanych.

Otwierający tom studiów tekst Agnieszki Gryglewskiej („Wokół Elisabetanum. Proces kształtowania się założenia urbanistycznego na Polach Stawowych przed rokiem 1945”) poświęcony został koncepcjom zagospodarowania przestrzennego części Przedmieścia Świdnickiego, złożonej z przyłączonych do Wrocławia w roku 1868 kilku podmiejskich wsi. Omówione i zaprezentowane zostały kolejne fazy kształtowania się założenia urbanistycznego związanego z powstaniem największego w mieście zespołu gmachów przeznaczonych dla instytucji oświatowych, ochrony zdrowia i opieki społecznej, dla dynamicznie rozwijającej się nowej dzielnicy mieszkaniowej. Autorka szczegółowo opisuje pomysły urządzenia na tym terenie parku leśnego związanego z ewangelickim kościołem Zbawiciela (projekt H. Lüdtkego i C.J.Ch. Zimmermanna), dwa plany parku połączonego z zabudowa czynszową - A. Kaumanna i A. Hoffmana, aż po zrealizowany na przełomie XIX i XX w. projekt Alfreda von Scholtza i Alfreda Frühwirtha, będący udanym przykładem tzw. założenia rozproszonego. Czytając o projektach urbani- 
stycznych owych czasów i mając przed oczyma rysunki projektów współczesny czytelnik - stykający się na co dzień z beztroskim chaosem współczesnej zabudowy miejskiej - może popaść w stan głębokiej frustracji. Autorzy projektów myśleli o wszystkim zarówno o potrzebach ciała (place zabaw i tereny parkowo-rekreacyjne, place targowe dla poszczególnych fragmentów dzielnic, instytucje ochrony zdrowia i opieki społecznej), jak i ducha (świątynie, instytucje oświatowe i kulturalne). Tereny zielone nie były traktowane jako zbędny luksus i rezerwuar ziemi dla nowych inwestycji budowlanych, lecz stanowiły naturalną część miasta, a większe ogrody miały łączyć się dzięki szpalerom drzew, którymi obsadzane były wszystkie ulice. Autorka opisuje nie tylko budynek Elisabetanum, ale sporo miejsca poświęca gmachom przeznaczonym dla szkół, przedszkoli, szpitali, sanatoriów i domów opieki społecznej położonym w rejonie obecnych ulic Joannitów, Glinianej, Jana Władysława Dawida i Dyrekcyjnej. Tekst opatrzono obfitym materiałem ikonograficznym, licznie prezentowane są przedwojenne zdjęcia budynków i detali architektonicznych, potwierdzających opinię Autorki, że urbanistom i architektom tworzącym projekt zabudowy Pól Stawowych udało się sprostać wymaganiom „piękna i funkcjonalności”.

Kolejny z tekstów autorstwa Jolany Szablickiej-Żak omawia powojenne dzieje szkół i placówek opiekuńczych (,Wokół dawnego Elisabetanum. Historia szkół oraz placówek oświatowych i opiekuńczych w rejonie ulic Jana Władysława Dawida, Joannitów i Glinianej po 1945"). Możemy poznać dzięki niemu powojenne losy budynków szkolnych ocalałych po długotrwałym oblężeniu Wrocławia i wyburzeniach uszkodzonych gmachów przeprowadzonych przez władze polskie po 1950 r. (szczególne wrażenie sprawia zestawienie dwóch zdjęć ulicy Komandorskiej z 1945 i 1965 r. (s. 50)). Konieczność kształcenia kadr nauczycielskich dla odbudowywanego szkolnictwa spowodowała, iż w gmachu Elisabetanum - jako jednym z najlepiej zachowanych budynków szkolnych - utworzono Państwowe Liceum Pedagogiczne nr 1, a następnie II Studium Nauczycielskie i Wyższe Studium Nauczycielskie. Losom tych instytucji, a także zajmujących sąsiednie gmachy Gimnazjum i Liceum Budowlanego oraz Państwowego Liceum Komunikacyjnego i Państwowego Liceum Geodezyjnego, poświęcona jest znaczna część tekstu. Jak w zwierciadle widać w losach omawianych instytucji oświatowych przemiany polityczne, społeczno-kulturowe i gospodarcze dokonujące się w okresie ostatniego półwiecza w naszym kraju. Dowodzą tego choćby losy Liceum Komunikacyjnego przekształconego z czasem w Technikum Kolejowe Ministerstwa Kolei i przeżywającego okres prosperity w latach PRL, a przekazanego w końcu lat 90. XX w. władzom samorządowym i tylko dzięki uporowi i determinacji kilku byłych dyrektorów i władz Ministerstwa Infrastruktury nietracącego swego specyficznego „kolejowego” profilu. Spadająca na władze szkolne konieczność utrzymania starych budynków o sporej kubaturze powoduje z kolei charakterystyczne dla naszych czasów zjawisko wynajmowania pomieszczeń szkolnych prywatnym instytucjom oświatowym. Rozdział kończy bardzo ciekawy opis tworzenia nowej tożsamości powojennego Wrocławia związanej ze zmianami w nazewnictwie ulic. Proces ten, obejmujący również tereny byłych Pól Stawowych, odbywał się w dwóch falach. Po 1945 r. starano się przede wszystkim polonizować nazewnictwo, nie przykładając wielkiej wagi do zgodności z narzucanym przez władze 
komunistyczne kanonem ideologicznym. Zmiany w tym zakresie nastąpiły dopiero po marcu 1948 r., kiedy to zmieniono kilkadziesiąt nazw ulic, mostów i placów, tak by odpowiadały ówczesnym wymogom poprawności politycznej. Obecna ulica Jana Władysława Dawida, nosząca przed 1945 r. nazwę Arletiusstraße, ku upamiętnieniu Johanna Caspara Arleta, rektora Gimnazjum św. Elżbiety, przemianowano początkowo na Opatowską, później na Bożogrobców, by ostatecznie uznać za jej patrona prekursora pedagogiki eksperymentalnej Jana Władysława Dawida.

Następny z rozdziałów, autorstwa Agnieszki Gryglewskiej poświęcono dokładnej charakterystyce budynku Elisabetanum („Gmach dawnego Gimnazjum św. Elżbiety na Polach Stawowych. Jego architektura jako odbicie tradycji szkoły"). Autorka opisuje założenia przyświecające architektom projektującym gmach „wspaniałego szkolnego pałacu”, Richardowi Plüdemannowi i Karlowi Klimmie, zawierające się w triadzie: „światło, powietrze, przestrzeń". Towarzyszące tekstowi liczne ilustracje pozwalają prześledzić kształtowanie się koncepcji architektonicznej (zaprezentowano kilka wersji projektów budynku), ale także obrazują kunszt rzemieślników wykonujących detale architektoniczne gmachu. Wrażliwość estetyczna uczniów miała być, zgodnie z koncepcjami ruchu ochrony środowiska kulturowego, kształtowana w równym stopniu przez programy szkolne, co przez codzienny kontakt z dziełami sztuki znajdującymi się w gmachu szkolnym. Dekoracje, zwieńczenia kolumn, inskrypcje, rzeźby niosły ze sobą także treści programowe, uzupełnieniem dydaktyczno-moralnego przekazu sentencji miała być symbolika ze świata roślin i zwierząt: akant, wawrzyn, róża, winorośl, czy tak istotny dla symboliki germańskiej dąb, sowa, lew, pszczoły, motyle to tylko niektóre okazy z bogatej galerii zawierającej elementy symboliki antycznej, chrześcijańskiej czy germańskiej. Do dzisiaj może wzbudzać zachwyt zarówno inwencja artystów projektantów, jak i maestria rzemieślników wykonawców. Autorka z drobiazgową szczegółowością omawia kwestie związane ze stroną artystyczną tych specyficznych obiektów sztuki użytkowej, jak i obszernie charakteryzuje wszelkie nowinki techniczne wykorzystane przy urządzaniu gmachu gimnazjum (system niskociśnieniowego centralnego ogrzewania parowego, czy grawitacyjny system wentylacji sali gimnastycznej). Możemy się także dowiedzieć, komu zawdzięczamy wykonanie detali z piaskowca (berlińska firma Carla Schillinga) czy prac związanych z kowalstwem artystycznym (wrocławska firma Fenk\&Halfpaap und August Saal). Rozdział zamyka omówienie losów gmachu w latach 1903-1945, planowana rozbudowa została wstrzymana w czasie I wojny światowej, gdy gmach przekazano na potrzeby wojska. Okres międzywojenny przyniósł jedynie przebudowę części budynku, a podczas II z wojen światowych los obszedł się z nim wyjątkowo łaskawie.

Następne rozdziały pracy poświęcono dziejom instytucji związanych z Uniwersytetem Wrocławskim mających siedzibę w budynku przy ul. Jana Władysława Dawida. Otwiera je tekst Jolanty Szablickiej-Żak poświęcony dziejom Instytutu Pedagogiki („Historia Instytutu Pedagogiki Uniwersytetu Wrocławskiego”). Organizatorami Katedry Pedagogiki byli związani z Uniwersytetem Poznańskim uczeni: prof. dr hab. Stanisław Tync oraz dr Wincenty Ostrowski i mgr Stefan Kaczmarek, później dołączyli do nich historycy oświaty związani ze środowiskiem krakowskim prof. dr hab. Henryk Barycz i mgr Mirosława Chamcówna, która na trwałe związała swe losy z wrocławską uczelnią. 
Postępująca stalinizacja nauki doprowadziła rychło do likwidacji bądź reorganizacji wielu kierunków uniwersyteckich. W narzuconym kanonie nauk humanistycznych pedagogika i psychologia miały być traktowane czysto utylitarnie, jako dziedziny pełniące rolę czysto usługowe, dające studentom niezbędne podstawy do prowadzenia w przyszłości zajęć dydaktycznych. Dopiero odwilż 1956 r. umożliwiła prof. S. Tyncowi reaktywowanie studiów pedagogicznych, początkowo jedynie w formie eksternistycznej. Dalsza historia wrocławskiego Instytutu Pedagogiki w okresie PRL to dzieje ścierania się tych dwóch sposobów podejścia do nauk pedagogicznych, klasycznego - traktującego pedagogikę jako odrębną dyscyplinę naukową, i pragmatyczno-utylitarnego, wedle którego pedagogika miała służyć masowemu kształceniu przyszłych nauczycieli. To także okres ciągłych, nie zawsze przemyślanych reform i przekształceń organizacyjnych Instytutu, ale także czas, w którym znakomicie rozwijały się badania naukowe, owocujące pojawieniem się dwóch znaczących szkół naukowych związanych z Instytutem Pedagogiki środowiska historyków oświaty związanego z prof. Mirosławą Chamcówną, oraz uczniów prof. Stefana Kaczmarka - badaczy procesu dydaktycznego, zwłaszcza nauczania w szkołach wyższych. Przełom roku 1989 przyniósł nowe wyzwania w postaci zmieniających się wymogów rynku pracy, konieczności tworzenia nowych kierunków kształcenia i coraz silniejszej konkurencji ze strony uczelni prywatnych.

Dziejom Instytutu Psychologii Uniwersytetu Wrocławskiego poświęciły swój artykuł Maria Porębska, Maria Straś-Romanowska i Alina Czapiga („Historia Instytutu Psychologii Uniwersytetu Wrocławskiego"). Powstanie studiów psychologicznych we Wrocławiu związane było z postacią prof. Mieczysława Kreutza, przed wojną organizatora i kierownika Katedry Psychologii na Uniwersytecie Lwowskim. W maju 1946 r. powołano do życia Katedrę Psychologii, prowadzone przez jej pracowników zajęcia cieszyły się sporym zainteresowaniem, a ich publikacje zyskały wysoką ocenę środowiska naukowego. Rozwój Katedry został gwałtownie przerwany w 1952 r., kiedy to decyzją Ministerstwa Oświaty zlikwidowano wszystkie studia psychologiczne, poza ośrodkiem warszawskim. Psychologia, podobnie jak pedagogika, miała być traktowana utylitarnie i pragmatycznie, jedynie jako przedmiot służący kształceniu przyszłych kadr nauczycielskich. Studia pedagogiczne powróciły na Uniwersytet Wrocławski dopiero w 1967 r. Autorki koncentrują się na szerokim omówieniu aktywności naukowej środowiska wrocławskiego, wskazując na nierzadko prekursorski charakter tematyki badawczej podejmowanej w Katedrze Psychologii Uniwersytetu Wrocławskiego.

Historia Bibliotek Instytutu Pedagogiki i Instytutu Psychologii stanowi przedmiot dwóch kolejnych tekstów umieszczonych w prezentowanym zbiorze. Maria Bosacka przedstawia dzieje Biblioteki Instytutu Pedagogiki (,Zarys historii i współczesności Biblioteki Instytutu Pedagogiki Uniwersytetu Wrocławskiego”), a Izabela Indeka i Kiriakos Chatzipentidis piszą o księgozbiorze Instytutu Psychologii („Na początku nie było nic...: zarys historii Biblioteki Instytutu Psychologii Uniwersytetu Wrocławskiego"). Tytuł drugiego artykułu, zaczerpnięty z wypowiedzi prof. Marii Porębskiej, dobrze oddaje początki funkcjonowania zbiorów bibliotecznych obu Instytutów. Księgozbiór składał się z resztek rozproszonych zbiorów dawnego gimnazjum św. Elżbiety, oraz zabezpieczonych przez Bibliotekę Uniwersytecką książek w języku niemieckim. Dalsze lata przyno- 
szą walkę o ocalenie księgozbioru, w czasach gdy pedagogika i psychologia zniknęły jako kierunki studiów uniwersyteckich, konieczność borykania się z problemami lokalowymi i kadrowymi, przy jednoczesnym stałym zwiększaniu liczebności księgozbioru. Cezurę w dziejach Bibliotek stanowiło przeniesienie ich siedzib do gmachu byłego Elisabetanum przy ul. Jana Władysława Dawida 1. Nastąpiło ono w 1971 r. i pozwoliło na zwiększenie księgozbioru, poprawę wyposażenia i zatrudnienie dodatkowego personelu. Przełom XX i XXI w. przynosi komputeryzację i dostosowanie Bibliotek do wymogów nadchodzących wraz z rozwojem nowych technologii informacyjnych.

Książkę zamyka zbiór wspomnień uczniów i nauczycieli, wśród których wstrząsające wrażenie sprawia opowieść Piotra Popowa, ucznia Szkoły Ćwiczeń będącego świadkiem niszczenia pomocy szkolnych pozostałych po dawnym gimnazjum niemieckim. Szokować może fakt, iż wspomniane zdarzenie miało miejsce nie w latach czterdziestych, tuż po zakończeniu wojny, lecz w roku 1965. Tom opatrzono słowniczkiem zawierającym biogramy osób związanych z historią gimnazjum św. Elżbiety i Instytutów Pedagogiki i Psychologii Uniwersytetu Wrocławskiego, zestawieniem danych dotyczących projektów i budowy gmachu Elisabetanum (wykaz projektów i wykonawców prac budowlanych i dekoratorskich), kalendarium historii gmachu i instytucji z nim związanych, bibliografią oraz indeksem nazwisk i firm.

Książka stanowi ciekawą lekturę zarówno dla historyków edukacji, czytelników związanych z kręgiem wrocławskiego środowiska psychologów i pedagogów, pasjonatów historii Wrocławia, ale także dla osób spoza tych społeczności (czego osoba recenzenta jest dobrym dowodem). Zwraca uwagę bardzo staranne edytorskie opracowanie, bogata szata graficzna stanowiąca integralną część tekstu, dokładne opisy bibliograficzne (zawierające także adresy stron internetowych) - dbałość Autorów o każdy szczegół.

Marcin Kwiecień

\section{Joanna Król, To idzie młodość... Związek Młodzieży Polskiej w szkole średniej ogólnokształcącej w latach 1948-1957, Avalon, Kraków 2011, ss. 369}

DOI: 10.14746/BHW.2016.34.13

Joanna Król od lat konsekwentnie pisze na temat średnich szkół ogólnokształcących, robi to dobrze, ma lekkie i dobre pióro, obiektywne spojrzenie na minioną rzeczywistość, doskonały warsztat badawczy ${ }^{1}$. Z zainteresowaniem zatem przeczytałam jej najnowszą

1 J. Król, Uchronić przed zapomnieniem - średnie szkoły ogólnokształcące w województwie szczecińskim w latach 1945-1948, Wydawnictwo Naukowe Uniwersytetu Szczecińskiego, Szczecin 2005; eadem, Licea ogólnokształcace $w$ województwie szczecińskim w latach 1948-1961, Wydawnictwo Adam Marszałek, Toruń 2009. 